\title{
Increased lipid peroxides and inflammatory parameters in the retina adjacent to choroidal melanoma
}

\author{
Albert J Augustin, Thorsten Böker, Winrich Breipohl
}

\begin{abstract}
Oxidative tissue damage and inflammatory reaction were investigated in the neurosensory retina of five eyes with malignant choroidal melanoma and correlated to the distance from the tumour. The results showed elevated levels of both lipid peroxides (expressed as thiobarbituric acid reactive substances) and myeloperoxidase in the retina adjacent to the tumour. The values declined with distance from the tumour. The results indicate that production of oxygen free radicals contributes to tumour associated retinopathy.

(Br F Ophthalmol 1994; 78: 130-132)
\end{abstract}

Malignant tumours are believed to be rich in oxygen free radicals, ${ }^{1}$ which may lead to oxidative tissue damage (lipid peroxidation). Lipid peroxidation in turn causes a migration of inflammatory cells, such as neutrophilic granulocytes. These cells contain myeloperoxidase (MPO), an enzyme mostly active at the low $\mathrm{pH}$ levels typical of ischaemic tissues, such as those often found in tumours. ${ }^{2}$

The influence of the tumour on adjacent nontumour tissue - for example, tumour associated retinopathy, has been described by Damato and Foulds. $^{3}$

Lipid peroxide (LPO) and MPO levels in the retinas of five patients with choroidal melanoma were determined at various distances from the tumour, in an attempt to quantify the oxidative tissue damage induced by choroidal melanoma.

\section{Center of}

Ophthalmology,

Department of Clinical

Ophthalmology,

University of Bonn,

Germany

A J Augustin

T Böker

Center of

Ophthalmology, Division

of Experimental

Ophthalmology,

University of Bonn,

Germany

W Breipohl

Correspondence to:

Dr A J Augustin, Department of Clinical Ophthalmology, Sigmund-Freud-Strasse 25 D-53105 Bonn, Germany.

Accepted for publication 26 August 1993 underlying tissue using microsurgical forceps under the operating microscope.

The biochemical analysis was performed according to Ohkawa et $a l^{4}$ (LPO/TBARS) and
Bradley et $a l^{5}$ (MPO), as modified by Augustin and Lutz. ${ }^{2}$

\section{DETERMINATION OF LPO (TBARS)}

Samples from each position (TA $=$ apex of tumour, $\mathrm{TN}=$ near $(3 \mathrm{~mm}), \mathrm{TF}=\mathrm{far}(8-10 \mathrm{~mm})$ ) of the examined neurosensory retina $(n=4$, amounts of $12-14 \mathrm{mg}$ ) were homogenised in 0.9 $\mathrm{ml} 1 \cdot 15 \% \mathrm{KCl}$ for 30 seconds with an Ultra Turrax blender (Janke \& Kunkel, Staufen, Germany. The assay mixture consisted of $0.1 \mathrm{ml}$ of the homogenate, $2 \mathrm{ml}$ of $0.9 \% \mathrm{NaCl}, 0.2 \mathrm{ml}$ of sodium dodecylsulphate, and $3 \mathrm{ml}$ of TBA (thiobarbituric acid reagent, containing equal parts of $0.8 \%$ aqueous thiobarbituric acid and acetic acid). The mixture was heated for 75 minutes at $95^{\circ} \mathrm{C}$ and then cooled with tap water. The resulting stain was transferred into a stable organic layer by adding $5 \mathrm{ml}$ butanol (Uvasol, Merk AG, Darmstadt, Germany) and shaking the mixture vigorously. After centrifugation at $3000 \mathrm{~g}$ for 15 minutes, the samples were fluorimetrically evaluated at $515 \mathrm{~nm}$ excitation and 553 $\mathrm{nm}$ emission. Amounts of tetramethoxypropane served as external standards $(1,2$, and $3 \mathrm{nmol})$; these were assayed using the method described above. LPO values of the samples are reported as means of TBARS/g (SEM).

\section{DETERMINATION OF MPO}

To free MPO from the primary granules of neutrophilic leucocytes, samples from each position (TA, TN, TF) of the examined neurosensory retina $(\mathrm{n}=4$, amounts of $12-14 \mathrm{mg}$ ) were homogenised for 5 seconds in $3 \mathrm{ml}$ hexadecyltrimethyl ammonium bromide (HTBA) solution (0.5\% HTBA in $50 \mathrm{mM}$ phosphate buffer, $\mathrm{pH}$ 6.0) with an Ultra Turrax blender. The homogenate was sonicated for 10 seconds, freeze thawed three times, and centrifuged at $40000 \mathrm{~g}$ for 15 minutes at $4^{\circ} \mathrm{C}$, resulting in the formation of a stable pellet. The supernatant was assayed for MPO activity by spectrophotometry: $2.9 \mathrm{ml}$ of $50 \mathrm{mM}$ phosphate buffer, $\mathrm{pH} 6.0$, containing $0.167 \mathrm{mg} / \mathrm{ml}$ of $o$-dianisidine hydrochloride and $0.0005 \% \mathrm{H}_{2} \mathrm{O}_{2}$, together with $0.1 \mathrm{ml}$ of the supernatant. The change in light absorbance at $460 \mathrm{~nm}$ was measured with a spectrophotometer. MPO values of the samples are expressed as units/g tissue (SEM).

The SEMs were calculated from analyses of multiple tissue samples from each position specified (TA, TN, TF). All measurements of the same sample were taken twice. Student's $t$ test and analysis of variance were used for statistical 


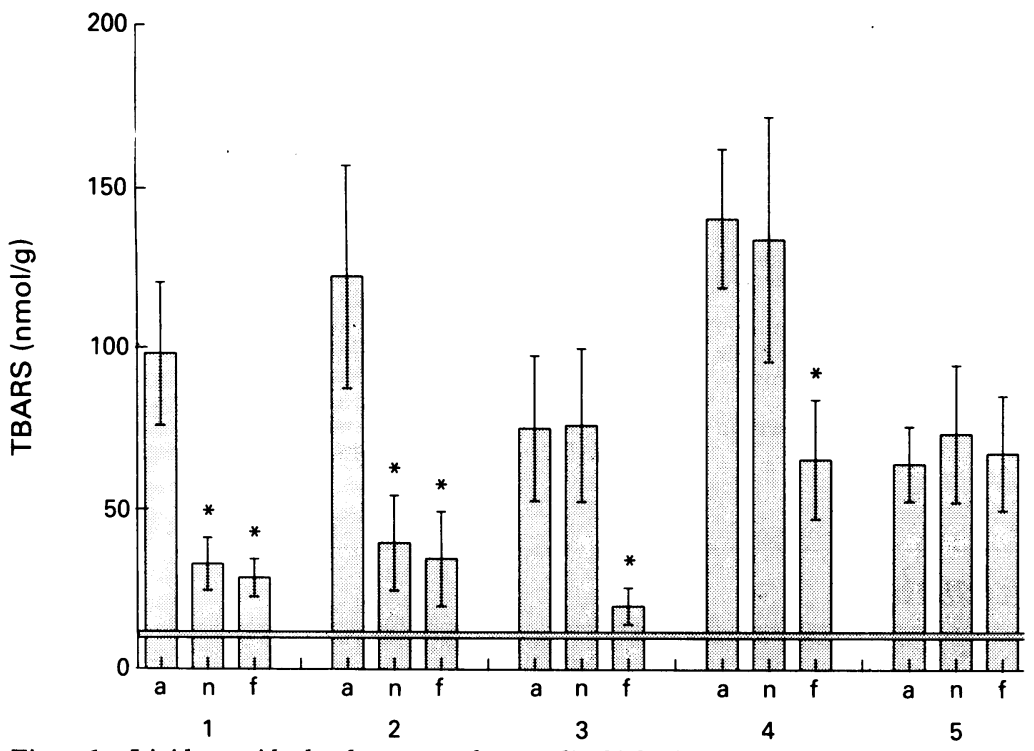

Figure 1 Lipid peroxides levels, expressed as nmol/g thiobarbituric acid reactive substances (TBARS), in the retina of tumour eyes: $a=$ apex of the tumour, $n=3 \mathrm{~mm}$ distance, $f=8-10$ mm distance. ${ }^{\star} p<0 \cdot 05$. Horizontal line $=$ value of patient No 6 .

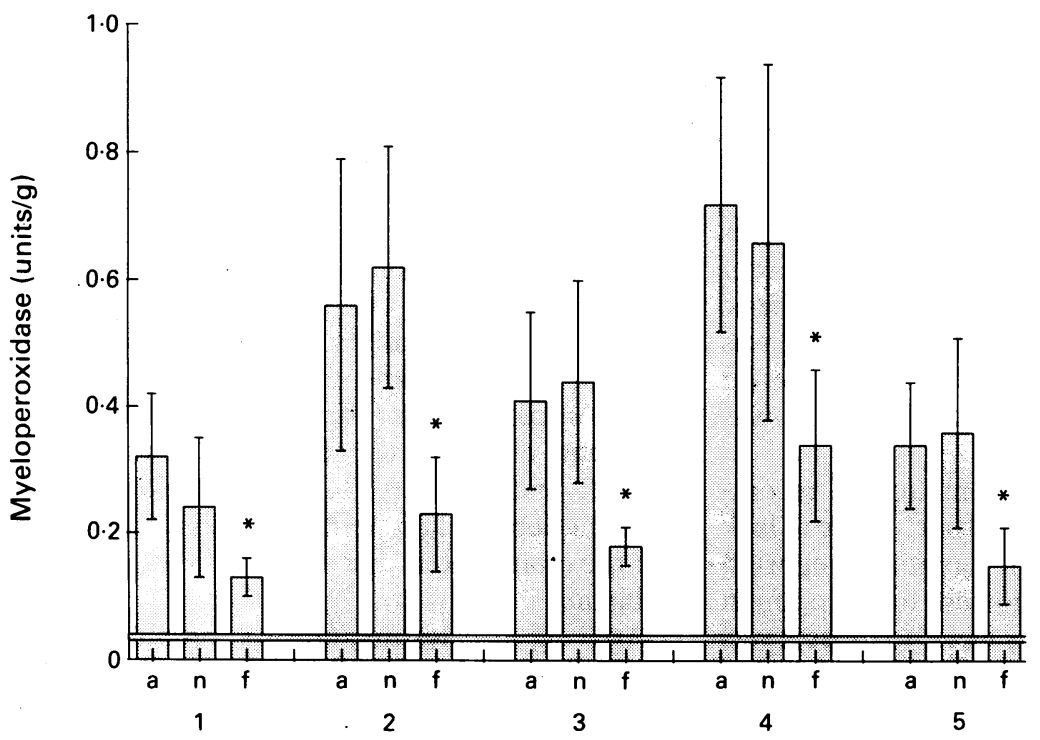

Figure 2 Myeloperoxidase levels in the retina of tumour eyes: $a=a$ apex of the tumour, $n=3$ $\mathrm{mm}$ distance, $f=8-10 \mathrm{~mm}$ distance. ${ }^{\dagger} \mathrm{t} p<0 \cdot 05$. Horizontal line $=$ value of patient $\mathrm{No} 6$.

Table 1 MPO and LPO (TBARS) levels (means (SEM)) of the retina at the apex of the tumour (TA), a distance of about $3 \mathrm{~mm}(T N)$ and a distance of about $10 \mathrm{~mm}(T F)$

\begin{tabular}{|c|c|c|c|c|c|c|}
\hline Patient & TA-MPO & TA-TBARS & $T N-M P O$ & TN-TBARS & $T F-M P O$ & $T F-T B A R S$ \\
\hline 1 & $\begin{array}{c}0.32 \\
(0.1)\end{array}$ & $\begin{array}{c}98 \cdot 2 \\
(22 \cdot 2)\end{array}$ & $\begin{array}{c}0 \cdot 24 \\
(0 \cdot 11)\end{array}$ & $\begin{array}{l}32 \cdot 8 \\
(8 \cdot 2)^{\star}\end{array}$ & $\begin{array}{c}0 \cdot 13 \\
(0.03)^{\star}\end{array}$ & $\begin{array}{l}28 \cdot 5 \\
(5 \cdot 9)^{\star}\end{array}$ \\
\hline 2 & $\begin{array}{c}0.56 \\
(0.23)\end{array}$ & $\begin{array}{l}122 \cdot 4 \\
(34 \cdot 9)\end{array}$ & $\begin{array}{l}(\mathrm{ns}) \\
0 \cdot 62 \\
(0 \cdot 19) \\
(\mathrm{ns})\end{array}$ & $\begin{array}{l}39 \cdot 5 \\
(14 \cdot 9)^{\star}\end{array}$ & $\begin{array}{c}0.23 \\
(0.09)^{\star}\end{array}$ & $\begin{array}{c}34 \cdot 6 \\
(14 \cdot 8)^{\star}\end{array}$ \\
\hline 3 & $\begin{array}{c}0 \cdot 41 \\
(0 \cdot 14)\end{array}$ & $\begin{array}{l}75 \cdot 3 \\
(2 \cdot 5)\end{array}$ & $\begin{array}{l}0.44 \\
(0 \cdot 16) \\
(n s)\end{array}$ & $\begin{array}{c}76 \cdot 3 \\
(23 \cdot 7) \\
(n s)\end{array}$ & $\begin{array}{c}0.18 \\
(0.03)^{\star}\end{array}$ & $\begin{array}{l}19 \cdot 9 \\
(5 \cdot 7)^{\star}\end{array}$ \\
\hline 4 & $\begin{array}{c}0.72 \\
(0.2)\end{array}$ & $\begin{array}{c}140 \cdot 9 \\
(21 \cdot 8)\end{array}$ & $\begin{array}{l}(\mathrm{ns}) \\
0 \cdot 66 \\
(0.28) \\
\text { (ns) }\end{array}$ & $\begin{array}{l}\text { (ns) } \\
134 \cdot 3 \\
(38 \cdot 2)\end{array}$ & $\begin{array}{c}0.34 \\
(0 \cdot 12)^{\star}\end{array}$ & $\begin{array}{l}65 \cdot 7 \\
(18 \cdot 5)^{\star}\end{array}$ \\
\hline 5 & $\begin{array}{c}0 \cdot 34 \\
(0 \cdot 1)\end{array}$ & $\begin{array}{c}64 \cdot 3 \\
(11 \cdot 6)\end{array}$ & $\begin{array}{l}\text { (ns) } \\
0 \cdot 36 \\
(0 \cdot 15) \\
\text { (ns) }\end{array}$ & $\begin{array}{l}\text { (ns) } \\
73 \cdot 7 \\
(21 \cdot 3) \\
\text { (ns) }\end{array}$ & $\begin{array}{c}0.15 \\
(0.06)^{\star}\end{array}$ & $\begin{array}{l}67 \cdot 6 \\
(17 \cdot 8) \\
(\mathrm{ns})\end{array}$ \\
\hline
\end{tabular}

Statistical analysis (Student's $t$ test and analysis of variance) compares TN and TF with the values of TA ( $n=$ not significant, $\left.{ }^{\star} p<0.05\right)$.

MPO=myeloperoxidase.

LPO $=$ lipid peroxides.

TBARS $=$ thiobarbituric acid reactive substances analysis. The level of significance was set at $\mathrm{p}<0.05)$.

\section{Results}

LPO (TBARS) and MPO values were found to be higher in the retina of eyes with choroidal melanoma than in the eye enucleated because of a perforating injury (Figs 1 and 2; Table 1). The levels were highest in the retina overlying the tumour and declined significantly with increasing distance from the tumour (except LPO (TBARS) in patient 5).

The levels at a distance of $8-10 \mathrm{~mm}$ from the tumour in undetached retina still exceeded the data of patient No 6 (TBARS $11 \cdot 2(2 \cdot 3) \mathrm{nmol} / \mathrm{g}$; MPO $0.03(0.01)$ units/g) by factors between 2 and 6 for LPO (TBARS) and 4 and 11 for MPO. Adjacent to the tumours, LPO (TBARS) and MPO levels were raised by factors of 10-24 (MPO) and 7-13 LPO (TBARS), respectively.

\section{Discussion}

This investigation showed that in choroidal melanoma an elevation of both LPO and MPO occurs in the adjacent retina. The degree of elevation is dependent upon the distance from the tumour. Our results suggest that elevated LPO and MPO levels may be the cause of or contribute to 'tumour associated retinopathy'. Tumour associated changes in the retina such as atrophy and cystic degeneration have been described by Damato and Foulds. ${ }^{3}$ They also describe a dedifferentiation of the retinal pigment epithelium (RPE), changes in the Bruch's membrane, and destruction of the choriocapillaris. ${ }^{3}$ It is conceivable that all of the above changes are related to the direct action of oxidative metabolites, which may originate in the tumour itself. ${ }^{6}$ While the tumour (and to some extent the RPE) might be protected by the fact that melanin acts as a free radical scavenger, the non-melanin containing tissues adjacent to the tumour (retina, Bruch's membrane, and choriocapillaris) could be at a higher risk of damage by oxidative metabolites. Elevated levels of oxidative metabolites in the tumour tissue such as LPO lead to a chemotactic attraction of leucocytes ${ }^{7}$ which are known to produce MPO; in turn MPO may enhance the LPO initiated oxidative tissue damage. Our data on the elevated levels of retinal MPO adjacent to the tumour suggest a migration of leucocytes and an increased inflammatory reaction in the retina in relation to the distance from the tumour. Whether an exudative retinal detachment (a part of the tumour associated retinopathy) by itself accounts for these findings cannot be deduced without the values of healthy, fresh retina and detached retina which, for obvious reasons, are not possible to obtain.

The MPO elevation could also result from factors other than local LPO levels. Waltz et al ${ }^{8}$ found that the melanoma growth factor leads to an increased oxygen uptake and a cytosolic content of $\mathrm{Ca}^{2+}$ in leucocytes. This 'respiratory burst' indicates an activation of leucocytes that can lead to enhanced MPO production. The findings presented suggest that the possible therapeutic effect of antioxidants should be 
investigated in the supporting treatment of retinopathy secondary to choroidal and ciliary body melanomas.

A part of this study has been presented at the meeting of the Ophthalmic Oncology Group of the European Organisation for the

1 Rotstein JB, Slaga TJ. Effect of exogenous glutathione on tumor progression in the murine skin multistage carcinogenesis model. Carcinogenesis 1988; 9: 1547-51.

2 Augustin AJ, Lutz J. Intestinal, hepatic and renal production of thiobarbituric acid reactive substances and myeloperoxidase activity after temporary artic occlusion and reperfusion. Life Sci 1991; 49: 961-8.

3 Damato BE, Foulds WS. Tumour-associated retinal pigment epitheliopathy. Eye 1990; 4: 382-7.
4 Ohkawa H, Ohishi N, Yagi K. Assay for lipid peroxides in animal tissues by thiobarbituric acid reaction. Anal Biochem 1979; 95: 351-8.

5 Bradley PP, Priebat DA, Christensen RD, Rothstein G. Measurement of cutaneous inflammation: estimation of . F Invest Dermatol 1982; 78: 206-9.

6 Dabrowska M, Prokopowicz J, Pietruczuk M, Kemona H Wolosowicz N, Kiluk S, et al. The activity of neutrophi myeloperoxidase in patients with lung carcinoma. Folia Haematol (Leipz) 1988; 115: 613-9.

7 McCord JM, Steven H, Stokes H, Wong K. Superoxide radical as a phagocyte-produced chemical mediator of inflammation. Adv Infl Res 1979; 1: 273-80.

8 Waltz A, Meloni F, Clark-Lewis I, von Tscharner V, Baggiolini $M$. $[\mathrm{Ca}+] \mathrm{i}$ changes and respiratory burst in human neutrophils and monocytes induced by NAP-1/interleukin-8, NAP-2, and gro/MGSA. F Leukocyte Biol 1991; 50: 279-86.

\section{History of ophthalmology}

\section{Ophthalmologists at war 1914-1918}

At the beginning of this troubled period, a committee of eminent ophthalmologists was urgently summoned by the War Office to consider soldiers' standards of vision. Up until then, those wearing glasses were rejected, but with the number of recruits needed, this rule was speedily revoked. (Rightly so; ophthalmologists at the front line later correlated the number of injuries from broken glasses with the number of glasses worn, and felt they presented no increased risk of injury.) This left them to revise the 'basic standard of vision.' One continental army was using the 1877 criterion of 'ability to detect another person at ten paces,' and clearly this was inadequate.

Unfortunately, the ophthalmologists' recommendations were never carried out, owing to lack of time. Wirgman served in Egypt and reported that visual defects of patients sent for his opinion from convalescent hospitals were 'so gross it was a matter of surprise that they had been passed at all.'

The primary presenting feature at the front was traumatic injury, and the subject of exenteration in front line hospitals was furiously debated. Many ophthalmologists felt that no eye should be removed without their specialist opinion, and bilateral removal only after at least two doctors agreed. Undoubtedly eyes which could have been saved were enthusiastically removed by non-ophthalmic surgeons, though at least the cases combining orbital wounds with gross skin lacerations were treated further back down the line.

It was realised that many of the eyes which were grossly mutilated had not been injured directly-Barrett notes cases where the projectile passed at least one inch away, yet the eye was destroyed, presumably by pressure waves from the blast. One eyed soldiers were invalided out, although some disagreed with this, saying that the chances of a second eye injury were minute. This did not hold true for one Australian who eluded the authorities to rejoin his regiment, and by great mischance was re-injured and had his other eye removed.
Barrett was perturbed on considering the number of foreign bodies seen, and was extremely grateful when the large magnet at Mensoureh was put at their disposal, where he sent his patients by the truckload. He noted with interest that the number of malingerers fell off when the specialist ophthalmic team arrived, presumably to put their pleas to some other specialty.

The great ophthalmological mystery of the war was night blindness. One officer noted that in the desert, his men were persistently tripping over the tent ropes at night, to his great annoyance, and he initially suspected malingering. However, it became clear that the phenomenon was widespread, and whereas Birch Hischfeld blamed 'general debility and perhaps alcohol,' Weekers felt the monotonous diet and overtiredness were to blame.

Arriving in Palestine, officers were infuriated by the hosts of native children who were persistently selling fruit to men while they were engaged in shelling the Turks. However, all the men who bought fruit recovered normal night vision and the cause, by implication, finally became clear.

Many agreed that patients with hysterical symptoms, as opposed to malingering, presented the greatest challenge. One soldier was completely blind for six months after shelling, with no apparent physical injury. Deviously, his specialist (who was, unsurprisingly, French) explained that a truly enormous operation was needed - the suturing of the optic nerves to the brain with silver wire. The patient was anaesthetised for an hour, then told that the operation had been performed. The 'placebo' procedure was successful: on removing the bandages, his sight returned.

FIONA ROMAN

Barret JW. Night blindness. Br f Ophthalmol 1930; 26: 282-3. Report of the committee appointed by the Ophthalmological Society to consider standards of vision desirable in the British Army. Br f Ophthalmol 1918; 2: 40-5.

Snowball T. Night blindness. Br f Ophthalmol 1921; 5: 230-2. Wirgman WC. Lancet 1915; 11: 1189-90. 